\title{
WHERE WAS ANCIENT ZION? ${ }^{1}$
}

\author{
Peter J. Leithart
}

\begin{abstract}
Summary
It is commonly assumed that 'Zion' refers to the temple mount or to the city of Jerusalem as a whole. By examining texts in Samuel, Kings, and Chronicles, the article demonstrates that 'Zion' in the historical books of the OT always refers to a specific area of Jerusalem, namely, the fortress that David conquered and named the 'City of David'. This shows a continuity of usage across several centuries, and raises the possibility that the Psalms and prophets sometimes use 'Zion' to refer to the Davidic city and its institutions. The article ends with a brief examination of some of these texts, and argues that the specifically Davidic understanding of 'Zion' offers fresh insight into the meaning of these passages.
\end{abstract}

I.

The consensus of recent scholarship is that ancient 'Zion' was located on the southern end of the Ophel ridge on the eastern side of the city of Jerusalem, and, as a corollary, that the hill now called 'Mount Zion', the 'upper city' in southwest Jerusalem, is a first-century or even a Byzantine misnomer. ${ }^{2}$ This represents a substantive change from earlier assessments, which took modern Zion as ancient Zion, ${ }^{3}$

\footnotetext{
1 I am grateful to the anonymous reader of an earlier draft of this paper for correcting several inaccuracies and pointing to useful bibliography, and also to my research assistant, Nate Smith, for chasing down several sources that were otherwise inaccessible to me.

2 An accessible summary of the evidence and discussion may be found in Y. Shiloh et al., 'Jerusalem: The Early Periods and the First Temple Period', in E. Stern, ed., New Encyclopedia of Archaeological Excavations in the Holy Land (4 vols.; New York: Simon \& Schuster, 1992), 2.696-716. Hershel Shanks goes so far as to assert that today 'everyone agrees' that the city was originally on the eastern hill (Jerusalem: An Archeological Biography [New York: Random House, 1995], 3).

3 See, e.g., C.R. Conder, The City of Jerusalem (New York: Dutton, 1909), 47: After arguing that ancient and modern 'Zion' are the same location and
} 
an identification that goes back at least to the first century $\mathrm{AD}$ and perhaps earlier. ${ }^{4}$ Though the supposed confusion of the ancient writers is unexplained, modern scholars have concluded that the Eastern ridge was the original site mainly for two reasons. First, the upper city on the western hill did not have a sufficient water supply to support a settlement. The Gihon spring, which supplied water to the city, is located at the foot of the eastern ridge in the valley of Kidron, and could easily supply water to a fortress on the ridge above. Moving water to the western hill, however, would have been difficult, and there is no archeological evidence of such a system. Nor could the upper city have been supplied by cisterns, which, Kenyon believed,

recognising that 'Zion' came to be a designation for the entire city, Conder concludes that 'there is one quarter [of the city] to which [the name Zion] should not be solely applied-namely, the small spur which is called Ophel in the Bible.' Also, C.F. Keil \& F. Delitzsch, Commentary on the Old Testament (10 vols.; Edinburgh: T \& T Clark, 1880, repr. Grand Rapids: Eerdmans, 1980), 2.315. G.A. Smith, by contrast, argued from topological and archeological evidence that Zion was originally on the eastern ridge (Jerusalem: The Topography, Economics and History from the Earliest Times to A.D. 70 [2 vols.; New York: A.C. Armstrong, 1908], 1.136-44).

4 Josephus certainly identifies the higher western hill with the stronghold captured by David from the Jebusites. This upper city, which is 'much higher' than the eastern hill, "was called the "Citadel" by king David' (War 5.4.1). Likewise in Antiquities 7.3.1, he writes that David first took the 'lower city' and then the 'citadel' (őkpo). Josephus also described how Simon the Maccabean leveled the 'citadel' so that it was lower than the temple (Antiquities 13.6), but the Eastern 'Zion' was naturally lower than the temple. Kenyon called Josephus's confusion on this point 'an unexplained mystery' (Digging Up Jerusalem [New York: Praeger, 1974], 37-38). It is more difficult to identify where the writer of 1 Mac. thought Zion was (1 Mac. 1:29-41), but Kenyon argues that this writer too identified the Western hill with Zion. She offers the following arguments: 1) 1 Maccabees 1 describes a Seleucid force occupying and fortifying a 'citadel' at the city of David, but if the wall of this citadel is identical to the wall that Kenyon discovered on the Eastern ridge, then the Seleucid force must have occupied the whole city, which runs contrary to the description of 1 Maccabees. 2) 1 Mac. 1:35-36 claims that the Akra dominated the temple, which would not be the case if the Akra were on the Eastern ridge. 3) According to 1 Mac. 13:49-50, Simon set up a siege to take the citadel, which kept the Syrians inside from being able to buy and sell, but if the citadel were on the Eastern ridge, Simon would have had to besiege the whole city, which Kenyon considers unlikely. Thus, Kenyon concludes that the Akra was the first building on the western hill during the postexilic period (ibid., 196-98). M. Ben-Dov, while denying that the western hill was Zion, defends Josephus's belief that the western hill was occupied in the first-temple period, suggesting that settlements extended to the eastern slope of the western hill some time between Uzziah and Manasseh (In the Shadow of the Temple: The Discovery of Ancient Jerusalem [ET I. Friedman; New York: Harper \& Row, 1985]), 34-36. For a brief summary of the archaeological debate concerning the Akra, see H. Geva, 'Jerusalem: The Second Temple Period', New Encyclopedia of Archaeological Excavations in the Holy Land, 2.723. 
were not serviceable until the invention of lime mortar, long after the time of David. ${ }^{5}$ Excavations on Ophel during the 1960s and 1970s, secondly, uncovered what is believed to be the wall of the old Jebusite fortress. According to Kenyon, 'It was originally built c. $1800 \mathrm{BC}$. It was still in use in the 8th century BC, and must therefore have been the wall of the Jebusite town that was captured by David, and that was thereafter repaired by him as the wall of his own city.' 6

Though the archeological evidence for identifying Ophel with ancient Zion is powerful, the case has not been proven beyond doubt, and questions and problems remain. Kenyon's belief that cisterns could not be used without lime plaster has been undermined by discoveries of much earlier cisterns. ${ }^{7}$ Discovery of a substantial and early wall on Ophel, furthermore, is conclusive evidence that there was a fortress or at least a walled city on that slope prior to the time of David, but the discovery does not in itself prove that the walled area on Ophel is the fortress that David conquered. No archeologist, after all, has found a 'Welcome to Zion' sign carved into the wall. Further, given the comparatively small size of what was a busy royal centre, ${ }^{8}$

5 See J. Baldwin, 1 \& 2 Samuel (Leicester: IVP, 1988), 200-201; Kenyon, Jerusalem: Excavating 3000 Years of History (New York: McGraw-Hill, 1967), $15-16$.

6 Kenyon, Royal Cities of the Old Testament, 26-27, quoted in Baldwin, $1 \& 2$ Samuel, 202. See the more recent detailed studies of Yigal Shiloh et al., eds., Excavations at the City of David (Qeden Monographs of the Institute of Archaeology 19, 30, 33, 35; Jerusalem: Hebrew University, 1984-1996).

7 John Peter Oleson, 'Water Works', $A B D$ 6.887-88.

8 Shiloh notes that the 'City of David, excluding the Temple Mount is small ... amounting to a little more than 12 a.' When the eastern slope, which was likely inhabited during the Late Bronze Age, is added, Jerusalem had a 'total urban area of approximately 15 a' ('Jerusalem', in New Encyclopedia, 2.699. This area included not only 'houses' of David (pl. in $1 \mathrm{Ch} .15: 1$ ), including the palace; other houses, including, presumably, that of Uriah and Bathsheba and of the Levitical personnel that served the tabernacle of David (Obed-edom alone had sixty-eight relatives [1 Ch. 16:38]); presumably quarters for David's personal bodyguard, which numbered 600 (2 Sa. 15:18) and their families (2 Sa. 15:22); and the royal tombs, which would likely have been marked by monuments of some sort, as well as additional tombs (see $2 \mathrm{Ch}$. 21:20;24:25). Admittedly, Jerusalem was only average or slightly below average in size for a Palestinian city. Early Bronze Age cities ranged from 10 to 20 acres, and even into the eighth century, denselypopulated cities like Lachish and Megiddo were under 20 acres (A.C. Myers, 'City,' in G.W. Bromily, ed., International Standard Bible Encyclopedia [4 vols.; Grand Rapids: Eerdmans, 1979], 1.707-710). Mesopotamian cities were much larger. Marc Van De Mieroop notes that there were wide variations in the sizes of cities during the second millennium, ranging from 20 hectares in Abu Salabikh to 75 hectares at Shubat Enlil, and later cities were larger still: Nineveh was 750 hectares, and Babylon 890 (The Ancient Mesopotamian City [Oxford: Clarendon, 1997] 95). 
the meager archeological findings from this area are surprising. John Monson concludes that, besides a terrace (identified with the biblical Millo), the wall discovered by Kenyon, and 'Warren's Shaft' that leads to the Gihon spring,

no hints of tenth-century occupation have been discovered. No tombs, no clear buildings, no certain lines of fortification, and certainly no temple have come to light. Most noticeable is the virtual lack of tenth-century pottery among the debris and fills of the later periods. Even a small settlement would produce substantial ceramic evidence, but so far such evidence is lacking. Various explanations have been offered, but none is entirely convincing. Jerusalem, for example, has been destroyed and rebuilt multiple times, and much of the City of David was disturbed and quarried for the construction of the late Roman city. But this still does not explain the dearth of tenth-century pottery.

Archaeologically speaking, the period in which Jerusalem received its social, political, and theological grandeur is still very much an enigma. The nature of the city in the tenth century BC is in fact one of the greatest mysteries in biblical archaeology. ${ }^{9}$

In the absence of indisputable evidence of Davidic buildings, fortifications, 'or pottery, the confidence of some archeologists about the location of ancient Zion is premature.

\section{II.}

It is not the burden of this essay, however, to defend the older identification of Zion, nor to offer an analysis of current archeological consensus. Instead, the essay will focus on the fact that Old Testament texts frequently distinguish geographically, and by implication theologically, between Zion on the one hand and the temple mount or the entire city of Jerusalem on the other.

This distinction is frequently ignored in contemporary biblical scholarship. Several of the contributors to the recent stimulating volume, Zion, City of Our God, seem to assume that 'Zion' and 'temple mount' are always interchangeable. Monson writes of the 'temple of Zion' and asserts that 'the temple and its setting lay at the heart of the Zion theology'.10 Gary Knoppers notes that Jehoshaphat's turn toward the temple when Jerusalem was under military threat supports the Chronicler's emphasis on the prominence of 'Zion'. ${ }^{11}$ In

9 John M. Monson, 'The Temple of Solomon: Heart of Jerusalem', in R.S. Hess \& G.J. Wenham, eds., Zion, City of Our God (Grand Rapids: Eerdmans, 1999) 56.

10 Monson, 'The Temple of Solomon', 8.

11 Knoppers, 'Jerusalem at War in Chronicles', in Zion, City of Our God, 68. 
a study of the Zion tradition in Ezekiel in the same volume, Thomas Renz claims that 'the question whether God dwells in Zion is dealt with in more detail in the first temple vision in chapters 8-11', and concludes that the insight that judgment begins at the sanctuary confirms 'the special role of Mt. Zion'.12 Similarly, in his monograph on the Zion tradition, Ollenburger claims that 'everything that can be said about Zion, and everything that took place within the Jerusalem cult' depends on Yahweh's presence on Zion, and goes on to cite a comment from Clements about the 'ideology of the Jerusalem temple'.13 Mazar claims that the threshing floor of Araunah, which David purchased as the temple site (2 Sa. 24) was on Zion, and that 'Zion' included the temple mount and the citadel even during David's reign. ${ }^{14}$ Though there are passages that support this identification, scholars have too often assumed that 'Zion' always refers to an area that includes the temple mount. I contend that in some passages, this identification is impossible, and new light is thrown on other passages if the distinction of Zion and the temple mount is maintained.

'Zion' is mentioned some 150 times in the Hebrew Bible, with the vast majority of these passages found in Psalms or prophetic books. These more 'poetic' uses of the word can be put to the side for the moment, since they do not give any direct evidence concerning the actual location of Zion. Psalm 48:2, for example, speaks of 'Mount Zion in the far north', but this is a symbolic rather than a literal description. Four passages in the historical books, however, provide information about the topography and location of Zion: 2 Samuel 5:7, 1 Kings 8:1, 1 Chronicles 11:5, and 2 Chronicles 5:2.15 Since David renamed 'Zion' the 'city of David', passages that refer to the 'city of David' will also be examined below. The point of this review will be to show that 'Zion' in the historical books of the OT always refers to a restricted area of the city of Jerusalem, and that this area is never identified with and does not include the temple mount.

12 'The Use of the Zion Tradition in the Book of Ezekiel', in Zion, City of Our God, 89.

13 Ben C. Ollenburger, Zion the City of the Great King: A Theological Symbol of the Jerusalem Cult (JSOTSS 41; Sheffield: JSOT, 1987), 23, citing R.E. Clements, God and Temple (Philadelphia: Fortress, 1965), 76.

14 Mazar, The Mountain of the Lord (New York: Doubleday, 1975), 41, 52-53.

15 In the following discussion, my assumption is that Chronicles is historically reliable and consistent with the presentation of Samuel and Kings. See J. Myers, I Chronicles. II Chronicles (New York: Doubleday, 1978), who summarises his position by saying 'the Chronicler's story is accurate wherever it can be checked, though the method of presentation is homiletical' (I.lxiii). 


\section{A. Zion}

2 Samuel 5 and 1 Chronicles 11 are parallel accounts of David's conquest of Jerusalem, and particularly of the 'stronghold of Zion'. Two conclusions may be drawn from these passages. First, it is clear that the stronghold is distinguished from the city as a whole (2 Sa. $5: 6-7 ; 1 \mathrm{Ch} .11: 4-5) .16$ The city is named 'Jerusalem' and 'Jebus', and these are clearly alternative names for the same civic whole $(1 \mathrm{Ch}$. 11:4).17 To be sure, David captured the whole city, but he did so by capturing the stronghold, which the Jebusites considered an impregnable fortress (2 Sa. 5:6). This double structure is typical of ancient city plans, which distinguished between an inner city fortress or acropolis and the surrounding city, which was also walled.

It is more difficult to determine what 'Zion' refers to in these pas-

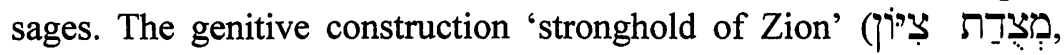
5:7) is inherently ambiguous. It could mean either 'the stronghold that is called Zion' or 'the stronghold that is in Zion', and in the latter case 'Zion' might be yet a third designation for the whole city. Several factors support the first of these interpretations. First, whatever 'Zion' refers to, David changed its name to the 'city of David' (2 Sa. 5:7; 1 Ch. 11:7). In the Chronicles account, David repaired this sector of the city after capturing Jebus ( $1 \mathrm{Ch} .11: 7-8)$, while Joab revived the 'rest of the city' (1 Ch. 11:8).18 Thus, repairing and rebuilding the 'city of David', which is also called 'the stronghold of Zion', is not equivalent to repairing and rebuilding the whole city. The 'city of David' is

16 Not every commentary is explicit about the location of 'Zion', but a number of commentators agree that the name refers to the fortress and not to the whole city. See R.P. Gordon, I \& II Samuel (Grand Rapids: Zondervan /Regency, 1986), 226; Baldwin, 1 \& 2 Samuel, 196; R.P. Bergen, 1, 2 Samuel (NAC 7; Broadman and Holman, 1996), 321; R.F. Youngblood, 1, 2 Samuel (Expositor's Bible Commentary; 12 vols.; Grand Rapids: Zondervan, 1976-1992), 3.854. McCarter (II Samuel [New York: Doubleday, 1984], 139) is the most explicit: The Ophel hilltop "was "the stronghold of Zion" or "the City of David" in the strict sense...; but as the city was extended, first north beyond the Ophel to include the temple mount (the present-day Haram esh-Sherif) and then west, the names "Zion" and "City of David" came to be used more broadly.' See also P. Ackroyd (The Second Book of Samuel [Cambridge: CUP, 1977] 56) and H.W. Hertzberg (I \& II Samuel: A Commentary [Philadelphia: Westminster, 1964] 268), though both state their conclusions more hesitantly than I have done.

17 היא is used in 1 Ch. 11:4 to introduce an appositional gloss, as in Gn. 14:3.

18 Ackroyd suggests that the second phrase may be better translated, 'Joab spared the rest of the population' ( $I \&$ II Chronicles, Ezra, Nehemiah [London: SCM, 1973] loc. cit.), but the context seems to favour some sort of building project. Ackroyd's suggestion, however, does not affect the conclusion that Zion and the city are distinct. 
equivalent to the stronghold and to Zion, but not equivalent to 'Jerusalem'.

More conclusively, the other two historical passages that refer to 'Zion' indicate that it was a restricted area within Jerusalem, and specifically the stronghold where David established his home and headquarters. 1 Kings 8:1 and 2 Chronicles 5:2 recount Solomon's transport of the ark from the 'city of David, which is Zion' to the temple. Both passages confirm that 'Zion' and 'city of David' refer to the same zone (using to identify the two in the same way that 1 Ch. 11:4 identifies Jebus and Jerusalem). Both, moreover, indicate that this zone was not coextensive with the city of Jerusalem, because the ark was taken out of Zion/the city of David though not out of Jerusalem. ${ }^{19}$ Finally, these passages indicate that the temple mount was considered a distinct area of the city from Zion, since the ark was taken 'out of' Zion to the temple. After this event, the ark was no longer on Zion, but on Moriah (2 Ch. 3:1).20

\section{B. City of David}

My goal in the following section is to establish that the referent of the phrase 'city of David' (עיר דִירוּר) is the same throughout the historical books, and that 'city of David' always refers specifically to the stronghold in Jerusalem, also known as Zion. Several groups of passages employ the phrase: descriptions of the housing arrangements for Pharaoh's daughter, the wife of Solomon; notices of building projects; and burial notices. We shall look at each set of passages in turn.

\section{The House of Pharaoh's Daughter}

Solomon brought the daughter of Pharaoh to the city of David until he had built a house for her, and upon completion moved her out of the city of David (1 Ki. 3:1; 9:24; 2 Ch. 8:11). Three observations demonstrate that the phrase refers to the fortress within the city. First, 1 Kings 3:1 states that Solomon placed Pharaoh's daughter in the city of David until he had finished several building projects, including 'the

19 See John Gray, I \& II Kings (2nd edn; London: SCM, 1970), 207.

$20 \mathrm{McCarter}$ (II Samuel, 139) cites $1 \mathrm{Ki} .8: 1$ as evidence of the restricted usage of 'Zion' and 'city of David.' Simon J. DeVries notes that the reference to the city of David in $1 \mathrm{Ki}$. 8:1 'included only Ophel with its citadel Zion', but makes an unfounded claim that the phrase had more expanded sense (including the temple mount) in David's day, though not in Solomon's (1 Kings [Waco: Word, 1985], 124). On 2 Ch. 5:2, see J. Barton Payne, 1, 2 Chronicles (Expositor's Bible Commentary; 12 vols.; Grand Rapids: Zondervan, 1976-1992), 4.459. 


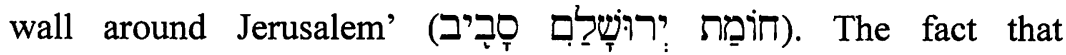
Jerusalem as a whole was not walled is thus presented as part of the rationale for setting up Solomon's new bride in the city of David. This makes sense if 'city of David' refers to the fortress: Solomon's wife, whose marriage to Solomon was part of an important alliance with Egypt (see $1 \mathrm{Ki}$. 9:16), was protected in the stronghold until a wall could be build around the whole city. If 'city of David' is merely an alternative name for 'Jerusalem', however, the reference to the walls makes no sense: Why would Solomon risk of putting Pharaoh's daughter in an unwalled city?

Second, 1 Kings 9:24 describes Pharaoh's daughter's move from the city of David to the house that Solomon built for her. There are several reasons to think that this house was also in Jerusalem, within the complex of royal buildings associated with the temple. The comment about the walls of Jerusalem in 3:1 is relevant here again: If Pharaoh's daughter was housed in a walled fortress until the city walls were finished, why would she then be moved out of the walled city?21 Further, the building of the new house for Pharaoh's daughter is recorded in 7:8, and the context indicates that it is part of the templepalace complex. Chapters 6-7 describe Solomon's building 'the house of YHWH' $(6: 1 ; 7: 51)$, but within this frame the author also describes Solomon's own house, the house of the forest of Lebanon, and the hall for Pharaoh's daughter. Theologically, these royal buildings were part of the 'house of YHWH', and it is likely that these buildings were geographically contiguous with the temple as well.22 Finally, 7:8 states

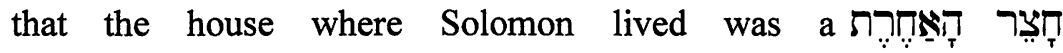

21 This tells particularly against DeVries (1 Kings, 133) who speculates, on the strength of the fact that she had to 'go up' from the city of David, that the house for Pharaoh's daughter was built on the Mount of Olives. But the Mount of Olives was certainly not fortified, and putting Pharaoh's daughter there would have placed the Egyptian alliance in jeopardy. DeVries's other suppositions are equally specious. He suggests that Pharaoh's daughter was moved out of the city 'because the queen grew tired of the hubbub of the city and demanded a quiet retreat somewhere else'. This is sheer speculation, and improbable speculation at that. As DeVries himself points out, 'her high position would preclude her being banished or in any way embarrassed' and speculates further that 'she continued to reside at least part of the time in her original palace adjacent to the king's'. All this can be avoided by the simple expedient of saying that the house of Pharaoh's daughter was built in Jerusalem, in the newly constructed temple complex. See R.D. Patterson \& H.J. Austel, 1, 2 Kings (Expositor's Bible Commentary) 4.43.

22 See Kenyon, Jerusalem, 58; Joan Comay, The Temple of Jerusalem (New York: Holt, Rinehart, Winston, 1975), 44; T.A. Busink, Der Tempel von Jerusalem von Salomo bis Herodes: Band I: Der Tempel Salomos (Leiden: Brill, 1970), 618; Mazar, Mountain, 53. 


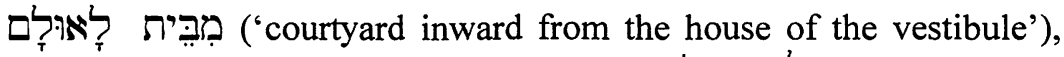

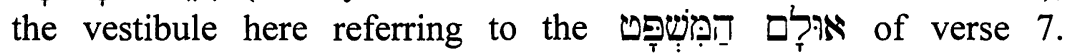
Solomon's own dwelling was separated by a courtyard from the hall of judgment, and the house of Pharaoh's daughter is immediately associated with Solomon's palace. This further suggests that the house for Pharaoh's daughter was also in Jerusalem. ${ }^{23}$ In short, if 1 Kings 9:24 describes a movement from one area of the city to another, 'city of David' in this passage refers not to Jerusalem but to the fortress of Zion.

Third, 2 Chronicles 8:11 indicates that Solomon brought Pharaoh's daughter out of the city of David 'because they are holy where the ark has entered'. At the time, the ark was in the fortress that David had conquered (see 2 Sa. 6:16-17; 1 Ch. 13:13), further confirming that the stronghold was the original Jerusalem home of Pharaoh's daughter.

\section{Building Projects}

Another set of passages describes various building projects in the 'city of David'. David built houses in the city of David (1 Ch. 15:1), Solomon 'closed the breach' in the city of David (1 Ki. 11:27), and Hezekiah strengthened the Millo in the city of David while rebuilding walls and towers ( $2 \mathrm{Ch} .32: 5)$. Again, the phrase in all these passages refers to the fortress area of Jerusalem. David's houses are described in tandem with the placement of the ark, which was carried into the fortress (1 Ch. 15:1). Solomon's efforts focused on repairing the Millo, which, whatever it actually was, is consistently associated with the fortress (2 Sa. 5:9; $1 \mathrm{Ki}$. 9:24). Hezekiah also rebuilt the Millo, and the fact that the rebuilding of the 'Millo [in] the city of David' is distinguished from rebuilding the 'wall' and the 'outside wall' further suggests that 'city of David' is being used in a restricted sense.

\section{Burial Notices}

The most common use of the phrase is in connection with burial notices. David, Solomon, Rehoboam, Abijah, Asa, Jehoash, Joram, Ahaziah, Joash, Amaziah, Azariah, Jotham, and Ahaz were all buried in the 'city of David' $(1 \mathrm{Ki} .2: 10 ; 11: 43 ; 14: 31 ; 15: 8,24 ; 22: 50 ; 2 \mathrm{Ki}$. $8: 24 ; 9: 28 ; 12: 20 ; 14: 20 ; 15: 7,38 ; 16: 20)$. There is too little

23 Harold Mare suggests that the 'royal quarter' occupied the area between the 'city of David' to the south and the temple site to the north, and that this quarter included the house of Pharaoh's daughter, which was located south of Solomon's own palace (The Archaeology of the Jerusalem Area [Grand Rapids: Baker, 1987], 70-73, 77). See also Gray, I \& II Kings, 158-59. 
contextual evidence to decide the meaning of the phrase in each case, but a strong argument can be made that each of these refers to the fortress area. 2 Chronicles 21:20 and 24:25, speaking of Jehoram and Joash respectively, record that these kings were buried in the 'city of David, but not in the tombs of the kings', indicating that there was a royal burial ground within the 'city of David'. This was doubtless the area in which David himself was buried; all the other kings in his dynasty were then buried around the tomb of the dynastic founder. If that is the case, then establishing the location of David's tomb should be sufficient to establish the location of the other royal tombs. 1 Kings 2:10 says that David 'slept with his fathers and was buried in the city of David'. All the other uses of the phrase in the surrounding chapters refer to the fortress of David $(3: 1 ; 9: 24 ; 11: 27)$, and there is simply no indication that the phrase is being used in a more expansive sense. ${ }^{24}$ Thus, the tombs of the kings were in the fortress area of Jerusalem, in the 'city of David'.

Though the final explicit references to the 'city of David' in burial notices appear in 2 Kings 16:20 and 2 Chronicles 27:9, Hezekiah was buried in the 'tombs of the sons of David' ( 2 Ch. 32:33:

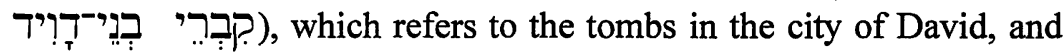
Josiah was likewise buried in the 'tombs of his fathers' ( 2 Ch. 35:24:

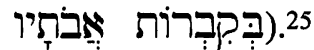

Nehemiah 3:15-16 may confirm this line of reasoning, though any conclusions about the form of the postexilic city must remain tentative. The passage describes the distribution of workers along the wall of the city. Shallum repaired the Fountain Gate, and then 'the wall of the Pool of Shelah at the king's garden as far as the steps that descend from the city of David'. Given the location of the Fountain

24 Gray (I\&.II Kings, 104) agrees that David's burial site was in the fortress, as does J. Robinson (The First Book of Kings [Cambridge: CUP, 1972], 39).

25 Ezk. 43:6-9 seems to count against the conclusion that the royal burial ground was in the fortress of Zion. In this passage, YHWH complains through the prophet

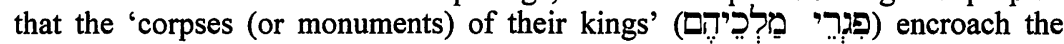
place where the Lord dwells and is enthroned. If this refers to the royal burial site, it indicates that the kings were buried near the temple rather than further south, but in fact it may refer only to the erection of royal stelae in the temple complex. The complaint is thus not that dead bodies defile the temple but rather that by erecting monuments near the Lord's house Judah's kings are attempting to compete with YHWH's own royal prerogatives. See L.C. Allen, Ezekiel 20-48 (Waco, TX: Word, 1990), 256-57. Alternatively, D. Block has noted that no tombs 'have been discovered near enough to the Solomonic temple grounds to be considered defiling

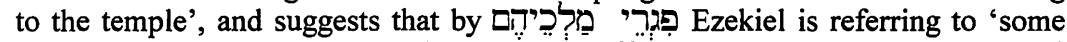
aspect of a cult of the dead', perhaps 'special offerings to the deceased' (The Book of Ezekiel [2 vols.; Grand Rapids: Eerdmans, 1997-1998], 2.584). 
Gate, ${ }^{26}$ the phrase 'city of David' again refers to David's old city, rather than to Jerusalem as a whole. Moreover, this whole passage is structured as a tour around the circumference of the city walls. Thus, the 'tombs of David' (קְברִי דָרוּיד) mentioned in verse 16 were located in the vicinity of the 'Fountain Gate', and the plural suggests that this area is the royal burial ground of the Davidic dynasty.

\section{III.}

On any reckoning, the texts examined above were written over a period of several centuries, and indicate that the name 'Zion' and the phrase 'city of David' had fixed meanings, referring to a specific portion of Jerusalem. Never in the historical books is the phrase used interchangeably with 'Jerusalem', and, importantly, this portion of Jerusalem was consistently distinguished from the temple district. In Psalms and prophetic books, the usage appears to be quite different, and indeed 'Zion' is used in an expanded sense in some Psalms and prophetic texts. Psalm 48:1-3 describes Zion as the 'city of the great King', which appears to be a reference to the whole city rather than the fortress alone. Similarly, Psalm 69:35 places 'Zion' on the same level as 'the cities of Judah', which implies that 'Zion' refers to one of those cities, and Isaiah prophesies of the redemption of 'Zion' (1:27) and calls Zion the 'city of our appointed feasts' (33:20). Certain texts use 'Zion' as a designation for the temple mount in particular, since they speak of the YHWH's present dwelling on Zion during the firsttemple period (Is. 8:18; 18:7; Joel 3:17).

The disparity between the usage in the historical books and the poetic and prophetic books may be accounted for in various ways. On the one hand, it might be argued that with the transfer of the ark to Mount Moriah (2 Ch. 3:1), the temple mount became a 'new Zion'. ${ }^{27}$ After Solomon, therefore, 'Zion' was used exclusively of the temple mount, while the phrase 'city of David' replaced 'Zion' as the designation of the old city, the fortress. This explanation accounts for the usage of 'city of David' in the historical books, but fails to account for the complete absence of Zion-language as a designation for the temple site in the historical books. Even so late a writer as the

26 It is commonly believed that the Fountain Gate was at the extreme southern end of the eastern ridge. See, for example, map 170 in Y. Aharoni and M. AviYonah, Macmillan Bible Atlas (rev. edn; New York: Macmillan, 1977).

27 This phrasing comes from W. Harold Mare, 'Zion', ABD 6.1096. 
Chronicler employs 'Zion' exclusively with reference to the fortress conquered by David, and pointedly states that the temple site was on Moriah (2 Ch. 3:1). Alternatively, it might be argued that 'Zion' retained its original meaning throughout the Old Testament period, always referring to the original site of David's capital and the original dwelling of YHWH in Jerusalem. This theory explains the usage of the historical books, but cannot explain the more expansive usage of the Psalms and prophets.

The proposal advanced here is that the truth is some combination of these two theories: 'Zion' remained closer to its original meaning than many scholars have assumed, and is used in certain Psalms and by certain prophets in its early, restricted sense, while at the same time, certain texts use 'Zion' to refer to a larger or a different area of the city, or to the people of Israel themselves. Since the idea that 'Zion' refers to the whole city or to the temple mount is widely acknowledged, there is no need for further development of that point here. However, the idea that some, perhaps many, passages in the Psalms and prophets use 'Zion' in its more restricted sense is an unexplored possibility and will be the focus of the following pages. The question to be posed is, How is the interpretation of the Psalms and prophets affected if 'Zion' means 'the fortress in Jerusalem' rather than 'temple mount' or 'Jerusalem' or 'Israel'?

Before examining several passages, it is important to review briefly what happened at Zion or the 'city of David' in David's time. Since Zion was the area of the city conquered by David, it was presumably in that sector that he built his palace (2 Sa. 5:11). It is therefore associated with the Davidic monarchy, and more particularly with David himself, as the original seat of the Davidic dynasty. Second, Zion was the place of YHWH's dwelling, the location of His first tentsanctuary in Jerusalem (2 Sa. 6:17; cf. vv. 12, 16). The worship established at the 'tent of David' was significantly different from the worship of the Mosaic tabernacle, which continued to function at Gibeon (1 Ch. 16:39-40). From what we can discern in the Pentateuch, the worship of the tabernacle included no music, apart from the trumpets that summoned the people to feasts (Nu. 10:1-10). With the erection of the Davidic tent, however, music, performed by a Levitical choir and orchestra, became one of the chief forms of liturgical action (1 Ch. 15-16), and this was later incorporated into the worship of the temple ( $1 \mathrm{Ch}$. 25). Finally, and perhaps most importantly, the Davidic tent, unlike the Mosaic tabernacle, was a single-room sanctuary, not divided into holy and most holy places. It 
was an ark shrine only, and symbolised and permitted greater degree of access than the Mosaic system with its multiple spatial and curtain barriers. ${ }^{28}$

This background makes sense of Psalms that claim to be from the period of David's reign, yet speak of YHWH dwelling on 'Zion'. These Psalms are often taken as post-Davidic, and YHWH's dwelling is assumed to be the temple. W. Harold Mare cites Psalms 9:11 and $76: 2$, among other passages, to illustrate his claim that 'Zion' is used for the temple mount. According to the title, Psalm 9 is a Psalm of David, and if the title is accurate, then verse 11 cannot refer to the temple, which was not yet built. ${ }^{29}$ Though many contest the accuracy of Psalm ascriptions, nothing in the content of the Psalm forbids Davidic authorship and the reference to YHWH's presence on Zion is consistent with David's reign (if 'Zion' is taken in the restricted sense discussed above), during which YHWH's throne was housed in the tent that David pitched for him.

Psalm 76 is titled a 'song of Asaph', certainly a reference to the Asaph that David placed in charge of the worship at YHWH's tent at Zion (1 Ch. 16:7). Again, the attribution is dismissed by most scholars, but no internal evidence supports this dismissal. The description of YHWH's dwelling as a 'booth' in Salem (v. 2 [Heb. v. 3]: (ספכ) is far more suited to the tent-sanctuary of David than to the temple of Solomon. Levenson's assertion that Psalm 78:68 identifies Zion as the temple mount has even less foundation in the text. ${ }^{30}$ Psalm 78 is attributed to Asaph, and the story line is clearly following the story of the ark as told in 1-2 Samuel. Verses 60-64 describe the desolation of the Shiloh sanctuary and the capture of the ark at the battle of Aphek (1 Sa. 4), and verses 65-66 recount YHWH's triumph over Dagon and the Philistines (1 Sa. 5-6). Following immediately

28 I cannot argue this point fully here. See my From Silence to Song: The Davidic Liturgical Revolution (Moscow, ID: Canon, forthcoming), for details.

29 If 'Zion' (v. 11) is the temple mount, the title is anomalous, and this anomaly is an argument in favour of the title's accuracy. A later editor would have been familiar with the Psalm and would have added Psalm's contents were consistent with the circumstances of David's reign. If, however, verse 11 refers to the temple, then the editor created unnecessary confusion by dating the Psalm back to David. Assuming that the editor had a modicum of intelligence, the preferable conclusion is that he had good reason to associate the Psalm with David and found nothing in the Psalm inconsistent with that association. More generally, I am assuming that the Psalm titles constitute reliable tradition, even if they were not part of the original text. For a defense of this position, see E.J. Young, An Introduction to the Old Testament (Grand Rapids: Eerdmans, 1949), 297-305.

30 Jon D. Levenson, 'Zion Traditions', $A B D 6.1100$. 
from this, YHWH chooses 'Judah' and 'Zion' and 'David his servant' (vv. 68-70), and in context this refers to His choice of the fortress Zion as the place for his ark-throne. There is no need at all to suppose that the Psalm refers to the reign of Solomon and the building of his temple, and thus no internal reason to doubt the ascription that associates the Psalm with Asaph.

A number of passages in the prophets promise a restoration of 'Zion' as shorthand for a restoration of the Davidic political and liturgical institutions. This is expressed most clearly in Amos 9:11, where the prophet predicts that YHWH will 'raise up the fallen booth

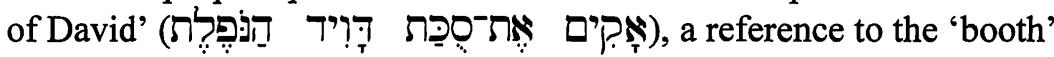
pitched on Zion. ${ }^{31}$ Though 'Zion' does not appear in the passage, Amos 9:11 indicates that the hope of Israel could be expressed as a hope for the restoration of Davidic; pre-Solomonic forms of worship. This suggests the possibility that other prophecies of Israel's restoration have the same focus, especially those that combine a promise of restored 'Zion' with the promise of a 'new David'. Isaiah $16: 1-5$, for instance, begins with an exhortation to bring sacrifices to 'the mountain of daughter Zion', and includes a promise that 'a judge will sit in faithfulness in the tent of David' (vv. 1, 5: דָּרוֹ Isaiah's prophecy concludes with a vision of Zion giving birth to sons (66:8), sons taken not merely from Israel but from the nations (vv. 2021). The hope that Gentiles will be taken for priestly ministry (v. 21) has a historical root during David's reign, when Gentiles served Yahweh at his shrine (2 Sa. 6:10-11).

Finally, a wider point may be made about the poetic and prophetic use of Zion. One of the oddities of Old Testament prophecy is that 'Moriah', the specific name of the temple mount, is never mentioned

31 Though the word for 'tent' in $2 \mathrm{Sa} .6: 17$ is and is used in Ps. 78 to refer to the Davidic sanctuary. Interpreting Am. 9:11 as a reference to the Zion tent is at least as plausible as other readings. D. Stuart (Hosea-Jonah [Waco: Word, 1987], 398) suggests that it is a place name, Succoth, referring to the town from which David launched some of his campaigns (citing Pss. 60:6 \& 108:7). Stuart's suggestion is unlikely and in any case conflicts with the interpretation given this passage by the Jerusalem Council, which clearly saw the Amos passage as a prophecy a restoration of the 'tent' of David (Acts 15:16-18; 'tent' translates $\sigma \kappa \eta v \eta)$. F.M. Cross more plausibly suggested that 'Amos 9:11 and Isaiah 16:5 preserve memories of the Davidic Tent of Yahweh. ... [Amos] is drawing on the typology between the dynasty and the dynastic shrinethe Tent of Yahweh' ('The Priestly Tabernacle in the Light of Recent Research', in A. Biran, ed., Temples and High Places in Biblical Times (Jerusalem: Keter, 1981), 177, fn. 31, cited in S.M. Paul, Amos (Minneapolis: Fortress, 1991), 290, fn. 18. 
by name. ${ }^{32}$ Whenever the mount of YHWH's dwelling is mentioned, it is always called 'Zion'. Even if the referent of these texts is the temple mount, it is significant that the name used is Zion. By employing 'Zion' rather than 'Moriah', these texts cart along baggage from the earlier, more restricted usage of the word: References to Zion in the prophets hearken back specifically to David's reign as the 'golden age' that will one day be re-established. That is to say, promises of a restored Zion are promises of the order of worship and life inaugurated in the new covenant, by a Son of David who has brought His people into an undivided sanctuary in a heavenly Zion.

32 Moriah is mentioned by name only twice in the OT: Gn. 22:2 \& 2 Ch. 3:1. 